Article

\title{
Environmental Implications of Taiwanese Oolong Tea and the Opportunities of Impact Reduction
}

\author{
Yi-Wen Chiu
}

Natural Resources Management and Environmental Sciences, California Polytechnic State University, San Luis Obispo, CA 93407, USA; yichiu@calpoly.edu; Tel.: +1-805-756-2972

Received: 8 October 2019; Accepted: 29 October 2019; Published: 31 October 2019

\begin{abstract}
Tea is the second most consumed beverage globally, yet its environmental implications are largely unknown. To overcome this knowledge gap, life-cycle analysis was conducted aiming to quantify the environmental impacts associated with tea production and consumption. To achieve this objective, Oolong tea production in Taiwan was selected to investigate the life-cycle impact in global warming potential (GWP) and eutrophication potential (EP) associated with one serving of hot tea consumed in Taiwan domestically and the international market in the U.S. and U.K. The results indicate that each serving of Oolong tea can result in a total of $28.6 \mathrm{~g} \mathrm{CO}_{2}$-equivalent of GWP and $0.09 \mathrm{~g} \mathrm{~N}$-equivalent of EP. Over $52 \%$ of GWP and $44 \%$ of EP are associated with the tea's cultivation, in which the application and production of agrochemicals accounts for $90 \%$ of GWP and $98 \%$ of EP. International consumption can increase GWP and EP by $19 \%$ and $26 \%$, respectively, which is largely attributable to the change of cooking energy from natural gases to an electric-gas mixed scheme. The findings from this study articulate the environmental portfolio of Oolong tea. More importantly, we can identify opportunities to mitigate the environmental footprint of Oolong tea in order to advance future sustainability.
\end{abstract}

Keywords: Oolong tea; life cycle assessment; global warming potential; eutrophication; impact mitigation

\section{Introduction}

Black, green and Oolong tea are all produced from the leaves of the same species of plant, Camellia sinensis. Tea difference is due to the amount of oxidation the leaves receive during the processing stage. Black tea is fully oxidized, Oolong tea is partially oxidized, and green tea is not oxidized. The level of oxidation results in complex changes in flavor profiles and aromas of the tea leaves. Oolong teas produced in the mountainous regions of Taiwan rank as some of the most expensive and highly regarded teas in the world, due to their quality flavors. Teas from these regions are of such high quality due to specific cultivation practices, processing methods, and optimal growing conditions, such as subtropical climate, regions of high elevation, and prime agricultural soils. As of 2016, there were approximately 11,689 hectares of area under tea cultivation in Taiwan. Historically, Oolong tea has been a high-priced commodity and is the most expensive tea produced in Taiwan [1].

Globally, tea is the second most consumed beverage, with water being first [2]. Asia has been the leading producer of tea in international markets accounting for $83 \%$ of tea production globally from 1961 to 2016 [3]. In Taiwan tea production, Oolong tea accounts for about $90 \%$ of the country's total production, while the remaining 10\% accounts for green and black tea [4]. According to the same source, nearly $70 \%$ of tea was consumed domestically, while exports accounted for $30 \%$ in 2015 . In addition to this report, trends indicate that import of tea has increased, while export of tea has decreased in Taiwan [3]. Nonetheless, tea from Taiwan is priced substantially higher than its foreign 
competitors, which may suggest that while the quantity of exports has decreased, the value of exports has increased [1].

With the significance of tea in the global beverage market, there is an urgent need to put its environmental implications into perspective by adopting suitable analytical tool such as life-cycle assessment (LCA). LCA is a quantitative tool for systematically assessing the environmental impact potential associated with a product or a service through its life cycle. This approach has been standardized in ISO 14040 series and been widely adopted to determine environmental implications in various sectors [5-8]. It is also a common tool utilized to investigate the environmental portfolio of agricultural and food industry in order to verify the primary impact contributors [9-14]. As LCA can account for impact footprints under different scenarios, it has also been employed to quantify environmental implications associated with the change of consumption behaviors [15-17], and to identify best management practices for mitigating the impact footprint of a product or service [18-20]. The development of LCA is believed to have emanated from the need for identifying alternative packaging designs in the beverage industry around 1960s [21]. It is no surprise that numerous studies have selected LCA to articulate the environmental performance of the mainstream beverages in the market nowadays, including coffee [22,23], milk [24-26], soft drinks and alcohols [27-30]. Given the market interest, several studies made an attempt to quantify the environmental effects of black tea by adopting LCA. A recent study examined the environmental impacts of black tea produced in Malawian factories, focusing primarily on the processing stage [31]. The authors identified several significant sources of environmental impact, including boiler fuel combustion and stand-by diesel power generation. Additionally, the results demonstrated that producing $1 \mathrm{~kg}$ of black tea could result in an average global warming potential (GWP) amounting to $21.14 \mathrm{~kg} \mathrm{CO}_{2}$-equivalent $\left(\mathrm{CO}_{2 \mathrm{e}}\right)$ and a eutrophication potential (EP) of $0.0028 \mathrm{~kg} \mathrm{PO}$-equivalent $\left(\mathrm{PO}_{4 \mathrm{e}}\right)$, with regional variation. Another study quantified the environmental impacts of Darjeeling tea cultivated in Northern India by taking into account a cradle-to-gate system beginning with cultivation in India and ending with the consumption of tea at a household in Europe [32]. The authors of this study stated that a cup of tea $(250 \mathrm{~mL})$ could result in GWP ranging from 19.4 to $170 \mathrm{~g} \mathrm{CO}_{2 \mathrm{e}}$, with an average of $48 \mathrm{~g} \mathrm{CO}_{2 \mathrm{e}}$, in which approximately $70 \%$ was contributed by electricity consumption required for boiling water at the consumption stage [32]. Comparatively, some results have indicated that the processing stage only accounted for $13 \%$ to $15 \%$ of total impacts. These findings suggest the environmental significance of tea consumption as a stage, as compared to processing, and illustrate the value in expanding the system boundaries of tea analyses to include more stages of the product's life cycle. An extension of the previous study performed by Doublet and Jungbluth [32] was conducted shortly after in order to assess the change of Darjeeling tea LCA performance under different production scenarios [33]. This study aimed to not only quantify the environmental impacts of the product, but to ascertain the least and most impactful production scenarios in order to better inform the tea industry. By manipulating options regarding cultivation type, electricity mix, and transport type of tea, the study found that the disparity in impacts resulting from the various scenarios were ultimately negligible when compared to the impacts arising from the consumption phase [33]. Furthermore, even when accounting for less-impactful options at the production phase, boiling water at the consumption phase remains a key contributor to significant greenhouse gas emission [33]. Instead of focusing on the consumption phase, another LCA research using black tea production in Iran as a study case to identify impact hotspot associated with tea farming practices. The authors found that by improving energy and operational efficiency to adjust machinery performance and fertilizer application can have a significant effect on reducing the environmental impacts of tea by a magnitude up to $20 \%$ [34].

While these studies provide a basis for the environmental portfolio of black tea, there are still significant information gaps regarding other tea varieties. Therefore, this study aims to assess the LCA performance of Oolong tea produced in Taiwan in order to leverage the current knowledge of tea's environmental implication. The goals of this study were to (a) portray life-cycle impact associated with Oolong tea consumption in order to determine major impact contributors, (b) derive impacts 
associated with different consumer market distribution scenarios, and (c) determine opportunities for mitigating Oolong tea impact footprint.

The investigated production system represents tea cultivated and manufactured in Taiwan, followed by different consumption pathways that end in Taiwan, England, and the United States. The GWP in $\mathrm{g} \mathrm{CO}_{2}$ equivalent $\left(\mathrm{g} \mathrm{CO}_{2 \mathrm{e}}\right.$ ) and $\mathrm{EP}$ in $\mathrm{g} \mathrm{N}$ equivalent $\left(\mathrm{g} \mathrm{N}_{\mathrm{e}}\right)$ per tea serving were selected to present the results. The analytical procedure will allow us to derive a comparable set of results to illustrate the environmental portfolio of Oolong tea production and consumption under different market distribution schemes.

\section{Methods and Data}

Primary data regarding materials, energy, irrigation, fertilizers, agrochemicals, labor, and transport distances were collected during a field survey of two tea plantations located in Lugu, within Nantou County, Taiwan. The average temperature in this region ranges from $14{ }^{\circ} \mathrm{C}$ to $31^{\circ} \mathrm{C}$, with significant precipitation of $2600 \mathrm{~mm} /$ year. Tea plantations form one of the most significant land cover types blanketing this region, which has an average elevation of 750 to 1200 meters. Cultivation and production data were provided by two tea farmers with over 15 years of farming experience. Relevant input and output values are summarized in Table 1 below. Additional background data were compiled from EcoInvent v3.2 [35] and multiple government agencies in Taiwan [36-39] to quantify emissions from energy consumption during the roasting and consumption stages by factoring in regional energy mixes. The life-cycle inventory result is then converted to GWP and EP by utilizing the TRACI method (The Tool for the Reduction and Assessment of Chemical and Other Environmental Impacts) developed by the U.S. Environmental Protection Agency [40].

Table 1. Tea cultivation data on an annual basis, compiled from field survey in Taiwan.

\begin{tabular}{|c|c|c|c|c|c|}
\hline $\begin{array}{l}\text { Production } \\
\text { Phase }\end{array}$ & Category & Item & Unit & Value (Site 1) & Value (Site 2) \\
\hline \multirow[t]{12}{*}{ Cultivation } & Geographic & Elevation & $\mathrm{m}$ & 1065 & 750 \\
\hline & & Plantation area size & ha & 1.94 & 0.97 \\
\hline & Fertilizer & Fertilizer as $\mathrm{N}$ & $\mathrm{kg}$ & 883 & 1296 \\
\hline & & Fertilizer as $\mathrm{P}$ & $\mathrm{kg}$ & 96 & 270 \\
\hline & & Fertilizer as K & $\mathrm{kg}$ & 96 & 246 \\
\hline & & Organic fertilizer & $\mathrm{kg}$ & $9000 \mathrm{a}$ & $3800 \mathrm{~b}$ \\
\hline & Irrigation & Surface water & $\mathrm{m}^{3}$ & 130 & 65 \\
\hline & & Groundwater & $\mathrm{m}^{3}$ & 80 & 40 \\
\hline & & Tap water & $\mathrm{m}^{3}$ & 12 & 6 \\
\hline & Agrochemical & Herbicide (active ingredients) & $\mathrm{kg}$ & 0 & 70 \\
\hline & & Pesticide (active ingredients) & $\mathrm{kg}$ & 18 & 61 \\
\hline & Energy & Gasoline & $\mathrm{L}$ & 47.6 & 0 \\
\hline \multirow[t]{2}{*}{ Harvesting } & Transport (labors) & Distance & $\mathrm{km}$ & 30 & 40 \\
\hline & Product & Tea leaf (wet) & kg & 17,400 & 2160 \\
\hline \multirow[t]{8}{*}{ Manufacturing } & Material & Tea leaf (wet) & $\mathrm{kg}$ & 17,400 & 2160 \\
\hline & Energy & Gasoline & $\mathrm{kg}$ & 0 & 116 \\
\hline & & Diesel & $\mathrm{kg}$ & 1467 & 0 \\
\hline & & Electricity & $\mathrm{kWh}$ & 127 & 186 \\
\hline & & Natural gas & $\mathrm{kg}$ & 0 & 320 \\
\hline & Transport (labors) & Distance & $\mathrm{km}$ & 15 & $\mathrm{n} / \mathrm{a}$ \\
\hline & Transport (tea leaf) & Distance & $\mathrm{km}$ & 15 & 20 \\
\hline & Product & Loose tea (roasted, dry) & kg & 4350 & 432 \\
\hline \multirow[t]{5}{*}{ Packaging } & Material & Loose tea (roasted, dry) & $\mathrm{g}$ & 600 & 420,000 \\
\hline & Material & Plastic bags & $\mathrm{g}$ & 34 & 23,520 \\
\hline & & Tea can (as 2-mm tin plate) & $\mathrm{cm}^{2}$ & 72 & 50,554 \\
\hline & Energy & Electricity & Whr & 0.75 & 528 \\
\hline & Product & Cans of loose tea & item & 1 & 700 \\
\hline
\end{tabular}

a: Soybean hulls as fertilizer; b: Mix of soybean hulls, bone meal, and wood chip. Bold font indicates products or outputs from each production stage. 
Based on typical brewing methods in Taiwan, six grams of loose tea can make three servings of hot tea with $170 \mathrm{~mL}$ of boiled water per serving. Therefore, the functional unit is defined by following this practice on the consumer's end. For the purpose of consumption analysis, Oolong tea is shipped and consumed domestically in Taiwan, or internationally in the United States (U.S.) and the United Kingdom (U.K.) as a hypothetical market destination. A cradle-to-gate product system is established consisting of three major production phases: tea cultivation, loose tea roasting and manufacturing, and hot tea made at consumers. Impacts associated with capital development or machinery building is excluded. Final results were presented to quantify environmental impact associated with the consumption of one serving of tea. However, in order to put the magnitude of the impact into perspective, results were normalized by the total global warming potential and eutrophication potential per-capita in the U.S. in 2008 [41].

\subsection{Cultivation and Harvesting}

Tea farmers in Taiwan typically apply pesticide, herbicide, and both synthetic fertilizer and organic fertilizer such as soybean meal. A layer of wood chips can be incorporated for soil erosion prevention. However, the field survey did not specify what types of pesticides and/or herbicides were applied. As such, the production and application of unspecified herbicides and pesticides, as well as the corresponding emissions, were derived from Ecoinvent v3.2. To incorporate the normal practice of applying organic fertilizer in Taiwan tea plantations, a fertilizer mix consisting of soybean hulls, bone meal, and wood chips was created by following a ratio of 4:4:5. Synthetic fertilizer application and its corresponding proportional emissions were derived from other studies (Table 2) [42,43]. Irrigation water sources were a mix of tap water, groundwater, and surface water. We also took into account emissions from transporting farm workers and products, and that from farming machine operation. Lastly, because Oolong tea is considered to be high-price commodity, the farmers of both studied sites reported they only employ hand harvesting. Based on the field survey, these studied tea plantations reached an average yield of $6722 \mathrm{~kg}$ fresh tea leaves per ha per year.

Table 2. Assumption on emissions from synthetic fertilizer application [42,43].

\begin{tabular}{cccc}
\hline Emissions & Sink & & Output Parameters \\
\hline Ammonia & air & 0.060 & of kg N fertilizer applied \\
Nitrogen oxides & air & 0.017 & of kg N fertilizer applied \\
Dinitrogen monoxide & air & 0.017 & of kg N fertilizer applied \\
Nitrate & groundwater & 0.203 & of kg N fertilizer applied \\
Phosphorus & river & 0.003 & of kg P fertilizer applied \\
Phosphate & groundwater & 0.001 & of kg P fertilizer applied \\
\hline
\end{tabular}

\subsection{Manufacturing and Roasting}

Once fresh tea leaf is harvested, it is then transported from farms to factories nearby by using lightweight diesel- or gasoline-powered trucks. The process starts with sun drying in an airy open area and indoors to trigger withering and the fermentation process in tea leaf tissue, followed by a series of roasting steps to configure the balance between aroma and taste. In this stage, roasting contributed to energy usage, as well as transporting goods and labor. Energy consumption primarily occurs during the roasting process in the form of diesel, electricity, and natural gas in order to perform the following tasks: (a) tumbling, which involves a rotating cylinder as well as hand shuffling to promote further oxidation; (b) "kill green" occurs with the use of high temperature to ensure enzymes within the leaves are destroyed in order to stop further oxidation and achieve the partial oxidation characteristic of Oolong tea; and (c) rolling is followed where leaves are placed in a dish roller machine or a conveyor belt dryer. Secondary rolling and drying is often required in order to achieve better aroma or to eliminate any lingering moisture. The entire roasting process is one of the most critical 
stages that significantly affect the aroma and taste of tea. This energy-intensive process also gives Oolong tea very distinct flavor.

As Oolong tea roasting is an energy-intensive process, heat sources and consumption were investigated. Data indicated that liquefied petroleum gas (LPG) accounts for $96.8 \%$ of the so-called natural gas consumption in the public supply sector in Taiwan, whereas low-pressure natural gas makes up the rest $[37,38]$. This mix of heat sources was created as an energy input in the roasting stage specifically to represent the energy consumption regime at central Taiwan where tea was produced. After the roasting phases, each $\mathrm{kg}$ of fresh green leaves can yield $0.24 \mathrm{~kg}$ of loose tea leaves which is ready for packaging and shipping to markets.

\subsection{Packaging}

Materials used in packaging included tin-plated chromium steel for can production and plastic for bag production. The studied tea product represents a popular packaging scheme consisting of $600 \mathrm{~g}$ of loose tea leaves vacuumed sealed in a 34-gram plastic bag within a tin can. A tin can requires 2-mm equivalent tin-plated chromium steel sheet of $72.22 \mathrm{~cm}^{2}$ with a welding length of $18 \mathrm{~cm}$. The packaging, therefore, takes into account electricity usage for sealing the plastic liner and tin can, in addition to the packaging materials. Total electricity consumption in this stage is approximately 0.75 watt-hour per can. There was no transportation involved as the manufacturing facility, and the packaging facilities are located in the same place in these two cases.

\subsection{Consumption}

Two consumption schemes were developed to represent domestic market distribution and an international regime for the U.S. and U.K. To fulfill product shipment, we assumed that $70 \%$ of the product would be consumed in the U.S., while $30 \%$ would be consumed in the U.K. These two countries were selected as they have shown a strong increase of revenue in tea markets or tea consumption per capita. They also represent typical western countries where tea has primarily been imported to support their domestic demand [44]. All transportation distances were estimated in a population-weighted distance from Lugu, Taiwan, to all major cities in Taiwan, as well as in the U.S. and U.K. Domestic consumption occurring in Taiwan included transport with gasoline-powered trucks to the market in Taiwan, of which the cooking energy (for boiling water) primarily relies on a combination of LPG and natural gas. Therefore, we applied the same approach and data sources as what were shown in the roasting phase $[37,39]$ to create a national energy mix to represent the cooking heat source (Table 3). International consumption, on the other hand, includes both land and sea transportation. The energy sources for heating are proportionally varied by country to include electricity and natural gas, emissions of which were derived and aggregated from EcoInvent v3.2 [35]. Cooking energy and its corresponding emissions are estimated based on an integrated scheme derived from the U.S. and U.K., and is primarily sourced from natural gas and electricity (Table 4). For the U.S., it was assumed that $60 \%$ of households use electric stoves and $40 \%$ use natural gas stovetops, whereas in the U.K., $70 \%$ of households use electric stoves and others rely on natural gas stovetops.

Table 3. Total emissions from the cooking energy mix in Taiwan [37,39].

\begin{tabular}{ccc}
\hline Input Flow & Unit & Amount \\
\hline liquefied petroleum gas & $\mathrm{g}$ & 32.85 \\
\hline natural gas & $\mathrm{g}$ & 45.17 \\
\hline Output Flow & Unit & Amount \\
\hline Cooking energy mix, Taiwan & kcal & 1000 \\
\hline
\end{tabular}


Table 3. Cont.

\begin{tabular}{ccc}
\hline Emissions & Unit & Amount \\
\hline Carbon dioxide & $\mathrm{g}$ & 244.000 \\
\hline Carbon monoxide & $\mathrm{g}$ & 0.1060 \\
\hline Hydrocarbons, unspecified & $\mathrm{g}$ & 0.0194 \\
\hline Hydrocarbons, unspecified & $\mathrm{g}$ & 0.0154 \\
\hline Methane & $\mathrm{g}$ & 0.0208 \\
\hline Nitrogen oxides & $\mathrm{g}$ & 0.2140 \\
\hline NMVOC, non-methane volatile organic compounds, unspecified origin & $\mathrm{g}$ & 0.0208 \\
\hline Particulates, $<10$ um & $\mathrm{g}$ & 0.0130 \\
\hline Particulates, $<2.5$ um & $\mathrm{g}$ & 0.0122 \\
\hline Particulates, $>2.5$ um, and $<10 \mathrm{um}$ & $\mathrm{g}$ & 0.0126 \\
\hline Sulfur dioxide & $\mathrm{g}$ & 0.0000 \\
\hline Sulfur oxides & $\mathrm{g}$ & 0.0358 \\
\hline Suspended solids, unspecified & $\mathrm{g}$ & 0.0135 \\
\hline
\end{tabular}

Table 4. Total emissions from the cooking energy mix in the international market [35].

\begin{tabular}{|c|c|c|}
\hline Input & Unit & Amount \\
\hline electricity, low voltage | market for electricity, low voltage & kcal & 0.4985 \\
\hline electricity, low voltage | market group for electricity, low voltage & kcal & 0.1183 \\
\hline natural gas, low pressure | market for natural gas, low pressure & $\mathrm{cm}^{3}$ & 28.4312 \\
\hline Output & Unit & Amount \\
\hline Cooking energy mix, Intl & kcal & 0.9110 \\
\hline Flow & Unit & Amount \\
\hline Acetaldehyde & $\mathrm{kg}$ & $1.33 \times 10^{-12}$ \\
\hline Acetic acid & $\mathrm{kg}$ & $1.99 \times 10^{-10}$ \\
\hline Benzene & $\mathrm{kg}$ & $5.30 \times 10^{-10}$ \\
\hline Benzo(a)pyrene & $\mathrm{kg}$ & $1.33 \times 10^{-14}$ \\
\hline Butane & $\mathrm{kg}$ & $9.28 \times 10^{-10}$ \\
\hline Carbon dioxide, fossil & $\mathrm{kg}$ & $7.43 \times 10^{-5}$ \\
\hline Carbon monoxide, fossil & $\mathrm{kg}$ & $1.03 \times 10^{-8}$ \\
\hline Dinitrogen monoxide & $\mathrm{kg}$ & $6.63 \times 10^{-10}$ \\
\hline Dioxins, measured as 2,3,7,8-tetrachlorodibenzo-p-dioxin & $\mathrm{kg}$ & $3.98 \times 10^{-20}$ \\
\hline Formaldehyde & $\mathrm{kg}$ & $1.33 \times 10^{-10}$ \\
\hline Heat, waste & MJ & $1.47 \times 10^{-3}$ \\
\hline Mercury & $\mathrm{kg}$ & $3.98 \times 10^{-14}$ \\
\hline Methane, fossil & $\mathrm{kg}$ & $2.65 \times 10^{-9}$ \\
\hline Nitrogen oxides & $\mathrm{kg}$ & $1.92 \times 10^{-8}$ \\
\hline
\end{tabular}


Table 4. Cont.

\begin{tabular}{ccc}
\hline PAH, polycyclic aromatic hydrocarbons & $\mathrm{kg}$ & $1.33 \times 10^{-11}$ \\
\hline Particulates, $<2.5 \mathrm{um}$ & $\mathrm{kg}$ & $1.33 \times 10^{-10}$ \\
\hline Pentane & $\mathrm{kg}$ & $1.59 \times 10^{-9}$ \\
\hline Propane & $\mathrm{kg}$ & $2.65 \times 10^{-10}$ \\
\hline Propionic acid & $\mathrm{kg}$ & $2.65 \times 10^{-11}$ \\
\hline Sulfur dioxide & $\mathrm{kg}$ & $7.29 \times 10^{-10}$ \\
\hline Toluene & $\mathrm{kg}$ & $2.65 \times 10^{-10}$ \\
\hline
\end{tabular}

\section{Results}

The results, as depicted in Figure 1, indicate the proportional GWP and EP associated with different Oolong tea production phases. Each serving of Oolong tea can result in a total of $28.6 \mathrm{~g} \mathrm{CO}_{2 \mathrm{e}}$ of GWP and $0.09 \mathrm{~g} \mathrm{~N}$ of EP if consumed in Taiwan. Shipping and consuming tea in the U.S. and U.K. amounts to additional $5.5 \mathrm{~g} \mathrm{CO}_{2 \mathrm{e}}$ of GWP and $0.02 \mathrm{~g} \mathrm{~N}_{\mathrm{e}}$ of EP compared to the Taiwan domestic market. The international scheme increases GWP and EP by $19 \%$ and $26 \%$ from the domestic system, which is primarily contributed by the lengthy transportation distance and the variance of cooking energy in different regions.

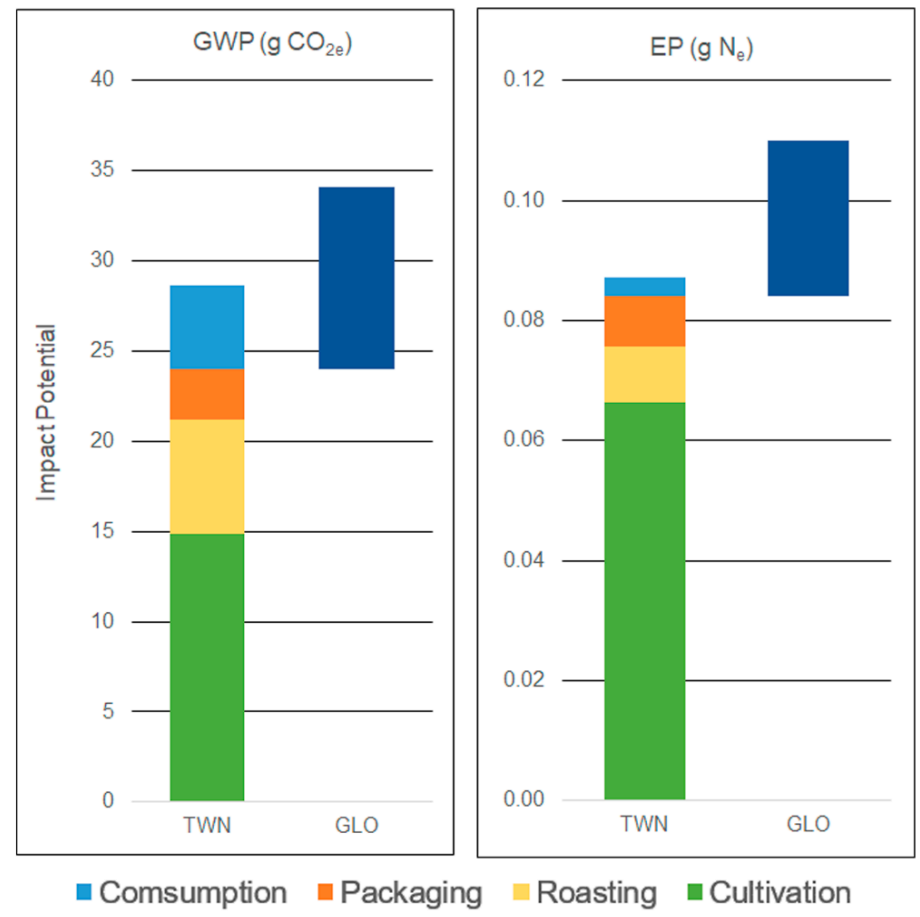

Figure 1. Proportional global warming potential (GWP, left) and eutrophication potential (EP, right) contributed by each Oolong tea production phase under domestic consumption in Taiwan (TWN) and in the global markets (GLO, dark blue bars). Figures show proportional change of impact magnitude of each production and consumption phase under different impact categories associated with 1 serving of Oolong tea.

\subsection{Global Warming Potential}

The largest GWP contributor throughout the life-cycle of tea production and consumption is the cultivation phase, accounting for nearly $52 \%$ of the total GWP associated with the domestic system. In the farming phase, the application of agrochemicals contributed approximately $31 \%$ of GWP in this production stage, consisting of the emission associated with broadcasting synthetic and organic 
fertilizers and pesticide. The rest of the emission is attributed to the up-stream impact embedded in the production of the agrochemicals (59\%), transportation (10\%), and irrigation (0.3\%).

Second in GWP impact was the tea manufacturing and roasting phase, which accounted for $22 \%$ of total GWP, followed by consumption (16\%) and packaging (10\%). Direct use of energy as a heat source for machinery operation (farming and roasting) and consumption (boiling water) appeared to be a significant impact contributor, accounting for $35 \%$ of total tea life-cycle GWP per serving. Due to the variations in heating sources between Taiwan and the international scheme, consuming tea in the U.S. and U.K. markets increases GWP by $19 \%$ compared to the domestic baseline, in which 13\% of the increase was associated with altered cooking energy, and the rest was attributed to extended transportation of international shipments.

\subsection{Eutrophication Potential}

The magnitude of change from the domestic market to an international is more significant in EP $(26 \%)$ than in GWP $(19 \%)$. However, the order of primary impact contributing phases remains the same in both impact categories except for the impact contributed by consumption (Figure 1). Proportionally, the cultivation phase in affecting EP is more significant than it is in GWP, as expected, accounting for $76 \%$ of total EP in Taiwan domestic market followed by manufacturing $(11 \%)$, and packaging $(10 \%)$. In the cultivation phase, substantial EP was contributed by the direct application of both organic and inorganic fertilizers, and the wood chips for soil protection (83\%). The rest of the impact can be attributed to the embedded EP from up-stream processes, including the production of fertilizer $(15 \%)$, and transportation (1\%).

The consumption phase only accounts for $4 \%$ of total EP under the domestic consumption scheme, whereas the international consumption would add additional $0.02 \mathrm{~g} \mathrm{~N}$ of EP to the domestic system, boosting a $26 \%$ increase of total EP. The change was primarily elevated by the shift of cooking energy ( $23 \%$ ) from primary sources observed in Taiwan to electricity-based stovetops adopted in the U.S. and U.K.

A normalized result was derived to illustrate the magnitude of GWP and EP in a comparable fashion. The per-person annual GWP and EP impact in the U.S. in 2008 [41] was adopted as a baseline to put the impact of consuming 500 servings of Oolong tea (made from approximately $1 \mathrm{~kg}$ of loose tea leaf) into perspective (Figure 2). The results indicate that EP is more of an environmental challenge than GWP in the life cycle of tea.

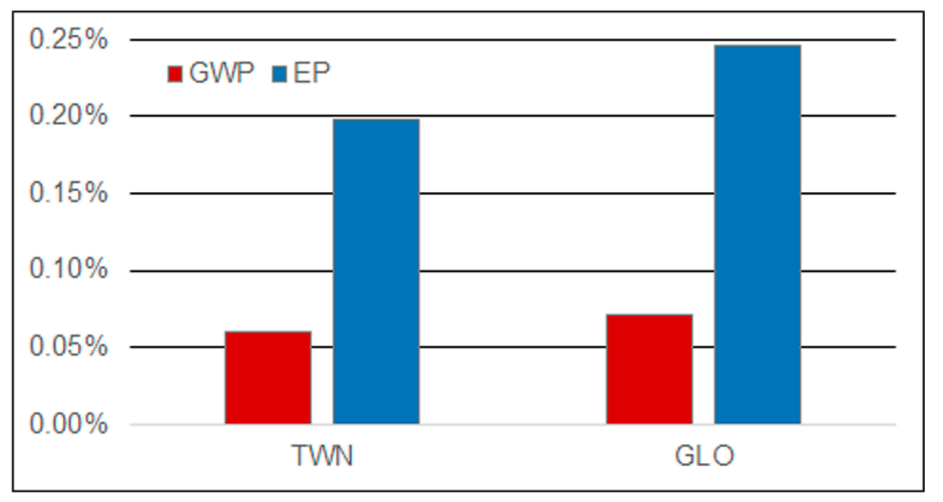

Figure 2. Normalized result of consuming 500 servings of Oolong tea, presented as a percentage of the magnitude of GWP and EP resulted from one person's average annual impact in 2008 in the U.S. as a baseline.

\section{Discussion: Opportunities for Impact Reduction}

The LCA method provides a broken down view of a product's life cycle and can identify the opportunities for impact reduction. However, as part of its methodology, LCA requires intensive data input in order to complete impact accounting. The collection of data inventory in Taiwan appeared to 
be a challenging task, because the local tea farms are family owned and have not yet been transformed to meet the same operational efficiencies as a large-scale commercial plantation. Therefore, most farming practices still rely on a farmer's judgement, along with experience that has been passed down over generations.

By comparison with black tea [31], Taiwan Oolong tea shows 52\% less GWP but 11 times higher EP per equivalent weight of loose tea. There are many factors contributing to these variations, including the geographical setting of tea farms that affect transportation requirements, and soil and climate characteristics that regulate framing practices. Therefore, the comparison between different tea types produced in different regions can only be employed as a reference to translate impact into a relevant perspective, rather than a comparison to determine the performance of each tea type.

\subsection{Systematic Data Collection and Schematic Configuration}

Neither of the interviewed farmers kept a booking system to track operations. There is little scientific reasoning behind the decision-making process either, with respect to the operational procedures or farming practices. This results in a widely varied material input scheme (Table 1). Using fertilizer as an example, the recommended inputs were 540,180, and $270 \mathrm{~kg} / \mathrm{ha}$ for N, $\mathrm{P}$, and K, respectively [45], whereas the field survey showed an average of 749,126 , and $118 \mathrm{~kg} / \mathrm{ha}$ of $\mathrm{N}, \mathrm{P}$, and $\mathrm{K}$. The field data in $\mathrm{N}$ fertilizer were $28 \%$ higher, but $43 \%$ and $130 \%$ lower in $\mathrm{P}$ and $\mathrm{K}$ fertilizers, than what was recommended. Using the domestic production system as an example, tea life-cycle GWP and EP per serving could be decreased by $11 \%$ and $13 \%$, respectively, if following the recommended fertilizer application rate.

On top of the use of synthetic fertilizer, local farmers also apply a significant amount of soybean-based organic matter as a nutrition supplement, with an average of $7267 \mathrm{~kg} / \mathrm{ha}$. The economic and biological benefits in responding to the use of organic fertilizer in tea cultivation remain unknown due to the lack of scientific evidence. Although there can be local soil characteristics that require such adjustment, the best management practices have not yet been examined due to the lack of scientific testing and analysis. It is also important to note that current GWP and EP assessment do not take into account the composition of woodchips, and hence, the potential impacts in the LCA scheme. As tea farmers in Taiwan generally recognize the utilization of woodchips to be an environmental-friendly practice, the potential environmental implications remain unknown. To tackle this challenge, more studies will be required in order to better understand the effectiveness and efficiency of improving tea environmental performance.

\subsection{Cultivation and Manufacturing}

The cultivation process accounts for nearly $52 \%$ and $44 \%$ of the total GWP in the domestic and international consumption pathways, respectively, and even greater in EP for $76 \%$ and $60 \%$ in domestic and international systems. This resonates with current practices for mitigating emission from tea plantations which take great emphasis on characterizing the non-point source water pollution associated with the use of agrochemicals [42,46-48]. Tea manufacturing is also known to be an energy intensive process due to the various steps necessary to produce adequate roasting levels. The steps include drying, withering, rolling, and heat treatment of leaves. This phase can be attributed to the large quantity of energy in various forms.

In addition to fertilizer as a known factor substantially affecting tea GWP and EP, the reduction of energy consumption for transporting farming goods and labor, operating machineries, and roasting is expected to decrease impact, although not as significantly as what could be achieved by agrochemicals. For instance, by reducing transportation distance by $50 \%$ in the cultivation phase, together with replacing 50\% electricity in roasting using natural gas, it is possible to achieve a $4 \%$ and $3 \%$ reduction of GWP and EP in the Taiwan local market. Although one might consider shortening transportation distances by $50 \%$ to be a challenging goal, this is in fact a feasible alternative, given the Taiwanese population's labor and market distribution. According to the tea farmers interviewed in this study, 
current farming practices have not considered energy efficiency or fuel reduction as strategies for mitigating environmental impact.

Moreover, in the studied case, only one type of packaging design was considered. A light-weight tin can that weighs $50 \%$ of the current design could eliminate an additional $4 \%$ of GWP and EP. Another packaging design using paper-based containers is also a popular alternative option in the market, which could decrease tea GWP and EP by approximately $8 \%$ if other packaging process remains the same. This demonstrates that a systematic approach is required to create a holistic impact reduction plan during the cultivation and manufacturing phases.

\subsection{Cooking Energy}

We found that GWP and EP associated with the international system were $19 \%$ and $26 \%$ higher than the domestic one, respectively. As the increase was attributed to the change of cooking energy rather than lengthening transportation distance, the result provides additional insight into mitigating the environmental impact of Oolong tea by targeting the consumption phase. Because significant impacts arise from the consumption stage in particular, it is important to recognize the value of sustainable consumptive practices.

The energy scheme for domestic consumption of LPG and NG resulted in less impact for each impact category relative to the energy scheme used for international consumption combining electricity and NG. The comparison between the domestic and international consumption schemes implies the importance of cooking energy in affecting tea's environmental portfolio. Cooking energy mix can contribute to $13 \%$ and $23 \%$ of GWP from a serving of tea in the domestic and international markets, respectively, whereas that accounts for $3 \%$ and $21 \%$ of EP under each system. Therefore, the choice of environmental impact categories can also have a significant effect on altering one's perception on how "green" Oolong tea can be.

For the purposes of this study, it was assumed that an exact amount of 170 grams of water was boiled to produce one serving of tea. In reality, many consumers may unnecessarily boil additional amounts, thereby increasing the amount of energy required to boil the water. This would result in additional impact at the consumption stage in both domestic and international scenarios. Thus, recommending that consumers to make a cup of tea by avoiding over boiling extraneous amounts of water, in fact, could have a meaningful contribution to mitigating tea's environmental impacts.

\section{Conclusions}

Despite the increasing interest in sustainable supply chain management of food products, environmental analyses of tea production and consumption have received less attention compared to other less-consumed beverages such as coffee. To this end, we performed a cradle-to-gate analysis of Oolong tea produced in Taiwan and compared impacts arising from consumption both domestically in Taiwan and internationally in the U.K. and U.S. Results of this study reveal the need to improve tea farming practices by incorporating scientific approaches and measurements, and to clarify the impact associated with the choice of cooking energy. Given these obtained outcomes, both tea producers and consumers can make strategic decisions to improve their environmental sustainability. During the tea cultivation phase, farmers should aim to optimize the fertilizer application efficiency in order to reduce eutrophication as its impact magnitude is over three times higher than GWP. Systematic approaches to mitigating tea environmental impact can be achieved by considering low-impact packaging designs, contracting with local workers, and avoiding excessive agrochemical applications. The quantitative results derived from this study provide insights to incorporate feasible solutions for mitigating tea environmental impacts. These can also serve as a baseline enabling analysis on impact reduction efficiency analysis in the future, which can benefit the tea industry to achieve sustainable goals in the long term.

Funding: The APC was funded by California State University Agricultural Research Initiative (ARI) Award No. 18-03-002. 
Acknowledgments: Special thanks to Deirdre Sommerlad-Rogers at Cal Poly for reviewing the draft, and to NRES graduates Jourdan Riedy and Samantha Hall for their lab assistance during the early stage of developing this project.

Conflicts of Interest: The authors declare no conflict of interest. The funders had no role in the design of the study; in the collection, analyses, or interpretation of data; in the writing of the manuscript, or in the decision to publish the results.

\section{References}

1. Etherington, D.M.; Forster, K. The structural transformation of Taiwan's tea industry. World Dev. 1992, 20, 401-422. [CrossRef]

2. Hicks, A. Review of global tea production and the impact on industry of the Asian economic situation. $A U J$. Technol. 2001, 5, 1-8.

3. Food and Agriculture Organization. FAOSTAT. Available online: http://www.fao.org/faostat (accessed on 22 January 2019).

4. Executive Yuan ROC Taiwan. The Republic of China Yearbook 2016. Available online: https://english.ey.gov. $\mathrm{tw} /$ (accessed on 13 January 2019).

5. International Organization for Standardization. ISO 14040: Environmental Management-Life cycle Assessment_-Principles and Framework; ISO: Geneva, Switzerland, 2006.

6. Marsmann, M. The ISO 14040 family. Int. J. Life Cycle Assess. 2000, 5, 317-318. [CrossRef]

7. Pryshlakivsky, J.; Searcy, C. Fifteen years of ISO 14040: A review. J. Clean. Prod. 2013, 57, 115-123. [CrossRef]

8. Guinée, J.B.; Udo de Haes, H.A.; Huppes, G. Quantitative life cycle assessment of products. J. Clean. Prod. 1993, 1, 3-13. [CrossRef]

9. Giraldi-Díaz, M.; Medina-Salas, D.; Castillo-González, E.; La Cruz-Benavides, D. Environmental Impact Associated with the Supply Chain and Production of Biodiesel from Jatropha curcas L. through Life Cycle Analysis. Sustainability 2018, 10, 1451. [CrossRef]

10. Adhikari, B.; Prapaspongsa, T. Environmental Sustainability of Food Consumption in Asia. Sustainability 2019, 11, 5749. [CrossRef]

11. Egilmez, G.; Kucukvar, M.; Tatari, O.; Bhutta, M.K.S. Supply chain sustainability assessment of the US food manufacturing sectors: A life cycle-based frontier approach. Resour. Conserv. Recycl. 2014, 82, 8-20. [CrossRef]

12. Haas, G.; Wetterich, F.; Geier, U. Life cycle assessment framework in agriculture on the farm level. Int. J. Life Cycle Assess. 2000, 5, 345. [CrossRef]

13. Heller, M.C.; Keoleian, G.A. Assessing the sustainability of the US food system: A life cycle perspective. Agric. Syst. 2003, 76, 1007-1041. [CrossRef]

14. Roy, P.; Nei, D.; Orikasa, T.; Xu, Q.; Okadome, H.; Nakamura, N.; Shiina, T. A review of life cycle assessment (LCA) on some food products. J. Food Eng. 2009, 90, 1-10. [CrossRef]

15. Wrieden, W.; Halligan, J.; Goffe, L.; Barton, K.; Leinonen, I. Sustainable Diets in the UK-Developing a Systematic Framework to Assess the Environmental Impact, Cost and Nutritional Quality of Household Food Purchases. Sustainability 2019, 11, 4974. [CrossRef]

16. Browning, M.; Crossley, T.F. The life-cycle model of consumption and saving. J. Econ. Perspect. 2001, 15, 3-22. [CrossRef]

17. Hertwich, E.G. Life cycle approaches to sustainable consumption: A critical review. Environ. Sci. Technol. 2005, 39, 4673-4684. [CrossRef] [PubMed]

18. Williams, H.; Wikström, F. Environmental impact of packaging and food losses in a life cycle perspective: A comparative analysis of five food items. J. Clean. Prod. 2011, 19, 43-48. [CrossRef]

19. De Benedetto, L.; Klemeš, J. The Environmental Performance Strategy Map: An integrated LCA approach to support the strategic decision-making process. J. Clean. Prod. 2009, 17, 900-906. [CrossRef]

20. Lundie, S.; Peters, G.M. Life cycle assessment of food waste management options. J. Clean. Prod. 2005, 13, 275-286. [CrossRef]

21. Hunt, R.G.; Franklin, W.E.; Hunt, R. LCA-How it came about. Int. J. Life Cycle Assess. 1996, 1, 4-7. [CrossRef]

22. Giraldi-Díaz, M.R.; Medina-Salas, L.D.; Castillo-González, E.; León-Lira, R. Environmental Impact Associated with the Supply Chain and Production of Grounding and Roasting Coffee through Life Cycle Analysis. Sustainability 2018, 10, 4598. [CrossRef] 
23. Coltro, L.; Mourad, A.; Oliveira, P.; Baddini, J.; Kletecke, R. Environmental profile of Brazilian green coffee. Int. J. Life Cycle Assess. 2006, 11, 16-21. [CrossRef]

24. Eide, M.H. Life cycle assessment (LCA) of industrial milk production. Int. J. Life Cycle Assess. 2002, 7, 115. [CrossRef]

25. De Boer, I.J.M.; Hoving, I.E.; Vellinga, T.V.; Van de Ven, G.W.J.; Leffelaar, P.A.; Gerber, P.J. Assessing environmental impacts associated with freshwater consumption along the life cycle of animal products: The case of Dutch milk production in Noord-Brabant. Int. J. Life Cycle Assess. 2013, 18, 193-203. [CrossRef]

26. Thomassen, M.A.; Dalgaard, R.; Heijungs, R.; de Boer, I. Attributional and consequential LCA of milk production. Int. J. Life Cycle Assess. 2008, 13, 339-349. [CrossRef]

27. Amienyo, D.; Gujba, H.; Stichnothe, H.; Azapagic, A. Life cycle environmental impacts of carbonated soft drinks. Int. J. Life Cycle Assess. 2013, 18, 77-92. [CrossRef]

28. Comandaru, I.M.; Bârjoveanu, G.; Peiu, N.; Ene, S.-A.; Teodosiu, C. Life cycle assessment of wine: Focus on water use impact assessment. Environ. Eng. Manag. J. 2012, 11, 533-543.

29. Neto, B.; Dias, A.C.; Machado, M. Life cycle assessment of the supply chain of a Portuguese wine: From viticulture to distribution. Int. J. Life Cycle Assess. 2013, 18, 590-602. [CrossRef]

30. Pattara, C.; Raggi, A.; Cichelli, A. Life cycle assessment and carbon footprint in the wine supply-chain. Environ. Manag. 2012, 49, 1247-1258. [CrossRef]

31. Taulo, J.; Sebitosi, A. Material and energy flow analysis of the Malawian tea industry. Renew. Sustain. Energy Rev. 2016, 56, 1337-1350. [CrossRef]

32. Doublet, G.; Jungbluth, N. Life Cycle Assessment of Drinking Darjeeling Tea. In Conventional and Organic Darjeeling Tea; ESU-services Ltd. Uster: Schaffhausen, Switzerland, 2010; Available online: http://www.avnir. org/documentation/bdd/sg/doublet-2010-LCA-Darjeeling-tea-1.0.pdf (accessed on 16 September 2018).

33. Cichorowski, G.; Joa, B.; Hottenroth, H.; Schmidt, M. Scenario analysis of life cycle greenhouse gas emissions of Darjeeling tea. Int. J. Life Cycle Assess. 2015, 20, 426-439. [CrossRef]

34. Kouchaki-Penchah, H.; Nabavi-Pelesaraei, A.; O’Dwyer, J.; Sharifi, M. Environmental management of tea production using joint of life cycle assessment and data envelopment analysis approaches. Environ. Prog. Sustain. Energy 2017, 36, 1116-1122. [CrossRef]

35. Ecoinvent Centre. Ecoinvent Data; Dübendorf, C.H., Ed.; Ecoinvent Centre: Zurich, Switzerland, 2018.

36. Taiwan Environmental Protection Administration. Taiwan Emission Data System (TEDS v. 9.0). Available online: https://erdb.epa.gov.tw/ (accessed on 3 October 2018).

37. Taiwan Bureau of Energy. Energy Balance Datasets. Available online: https://www.moeaboe.gov.tw/ECW/ populace/web_book/WebReports.aspx?book=B_CH\&menu_id=145 (accessed on 3 October 2018).

38. Taiwan Power Company. Taiwan Power Generation Potential by Sources. Available online: http://www. taipower.com.tw/content/new_info/new_info-c37.aspx (accessed on 23 June 2017).

39. Taiwan Power Company. Green House Gas Emission Factor. Available online: https://data.gov.tw/datasets/ search?qs=tid\%3A465\&order=downloadcount\&type=dataset (accessed on 3 October 2018).

40. Bare, J.C.; Norris, G.A.; Pennington, D.W.; McKone, T. TRACI-The Tool for the Reduction and Assessment of Chemical and Other Environmental Impacts. J. Ind. Ecol. 2002, 6, 49-78. [CrossRef]

41. Ryberg, M.; Vieira, M.D.; Zgola, M.; Bare, J.; Rosenbaum, R.K. Updated US and Canadian normalization factors for TRACI 2.1. Clean Technol. Environ. Policy 2014, 16, 329-339. [CrossRef]

42. Chen, C.F.; Lin, J.Y. Estimating the gross budget of applied nitrogen and phosphorus in tea plantations. Sustain. Environ. Res. 2016, 26, 124-130. [CrossRef]

43. Stoessel, F.; Juraske, R.; Pfister, S.; Hellweg, S. Life Cycle Inventory and Carbon and Water FoodPrint of Fruits and Vegetables: Application to a Swiss Retailer. Environ. Sci. Technol. 2012, 46, 3253-3262. [CrossRef]

44. Oloruntoba, A. Revenue of the Tea Market Worldwide by Country in 2018. Available online: https: //www.statista.com (accessed on 22 June 2019).

45. Huang, Y.M. Integrated Crop Management of Tea; Yang, S.J., Ed.; Council of Agriculture, Executive Yuan, Taiwan: Taipei, Taiwan, 2007.

46. Chou, W.S.; Lee, T.C.; Lin, J.Y.; Shaw, L.Y. Phosphorus load reduction goals for Feitsui Reservoir watershed, Taiwan. Environ. Monit. Assess. 2007, 131, 395-408. [CrossRef] 
47. Hirono, Y.; Watanabe, I.; Nonaka, K. Trends in water quality around an intensive tea-growing area in Shizuoka, Japan. Soil Sci. Plant Nutr. 2009, 55, 783-792. [CrossRef]

48. Wang, W.; Xie, Y.; Bi, M.; Wang, X.; Lu, Y.; Fan, Z. Effects of best management practices on nitrogen load reduction in tea fields with different slope gradients using the SWAT model. Appl. Geogr. 2018, 90, 200-213. [CrossRef] 